\title{
Prenatal diagnostic testing of the Noonan syndrome genes in fetuses with abnormal ultrasound findings
}

\author{
Ellen A Croonen ${ }^{1}$, Willy M Nillesen ${ }^{2}$, Kyra E Stuurman ${ }^{3}$, Gretel Oudesluijs ${ }^{4}$, Ingrid MBM van de Laar ${ }^{4}$, \\ Liesbeth Martens ${ }^{2}$, Charlotte Ockeloen ${ }^{2}$, Inge B Mathijssen ${ }^{5}$, Marga Schepens ${ }^{2}$, Martina Ruiterkamp-Versteeg ${ }^{2}$, \\ Hans Scheffer ${ }^{2}$, Brigitte HW Faas ${ }^{2}$, Ineke van der Burgt ${ }^{2}$ and Helger G Yntema ${ }^{\star, 2}$
}

In recent studies on prenatal testing for Noonan syndrome (NS) in fetuses with an increased nuchal translucency (NT) and a normal karyotype, mutations have been reported in $9-16 \%$ of cases. In this study, DNA of 75 fetuses with a normal karyotype and abnormal ultrasound findings was tested in a diagnostic setting for mutations in (a subset of) the four most commonly mutated NS genes. A de novo mutation in either PTPN11, KRAS or RAF1 was detected in 13 fetuses (17.3\%). Ultrasound findings were increased NT, distended jugular lymphatic sacs (JLS), hydrothorax, renal anomalies, polyhydramnios, cystic hygroma, cardiac anomalies, hydrops fetalis and ascites. A second group, consisting of anonymized DNA of 60 other fetuses with sonographic abnormalities, was tested for mutations in 10 NS genes. In this group, five possible pathogenic mutations have been identified (in PTPN11 $(n=2), R A F 1, B R A F$ and MAP2K1 (each $n=1)$ ). We recommend prenatal testing of PTPN11, KRAS and RAF1 in pregnancies with an increased NT and at least one of the following additional features: polyhydramnios, hydrops fetalis, renal anomalies, distended JLS, hydrothorax, cardiac anomalies, cystic hygroma and ascites. If possible, mutation analysis of BRAF and MAP2K1 should be considered.

European Journal of Human Genetics (2013) 21, 936-942; doi:10.1038/ejhg.2012.285; published online 16 January 2013

Keywords: Noonan syndrome; nuchal translucency; prenatal testing; mutation analysis

\section{INTRODUCTION}

Noonan syndrome (NS) is an autosomal dominant condition with an incidence of 1:1000-2500 live births. It is characterized by characteristic facies, short stature, congenital heart defects (CHD), skeletal abnormalities, cryptorchidism and variable development delay. ${ }^{1-3} \mathrm{NS}$ is one of the 'RASopathies', a specific class of developmental disorders, caused by germline mutations in genes, encoding proteins of the RASmitogen-activated protein kinase (RAS-MAPK) pathway. This pathway has an essential role in the control of the cell cycle, differentiation, growth and cell senescence. Dysregulation has profound developmental consequences. About $50 \%$ of known NS cases have a mutation in the PTPN11 gene. ${ }^{4,5}$ Heterozygous gain-of-function mutations in other genes perturbing RAS-MAPK signaling have also been identified in NS patients: KRAS, SOS1, BRAF, RAF1, MAP2K1, NRAS, SHOC2 and $C B L{ }^{6-13}$ Several of these genes are also involved in Cardio-FacioCutaneous (CFC) syndrome and Costello syndrome. ${ }^{14-16}$ Because of the high variability of clinical symptoms and the genetic heterogeneity establishing a diagnosis of one of these syndromes is often difficult. Patients are most frequently diagnosed postnatally, but also prenatal characteristic findings are described. Costello syndrome is associated with polyhydramnios, fetal overgrowth, a relative macrocephaly and to a lesser extent with nuchal thickening, hydrops, ventriculomegaly, pyelectasia and fetal atrial tachycardia/arrhythmia. ${ }^{17-19}$

Prenatal features of NS are increased nuchal translucency (NT), distended jugular lymphatic sacs (JLS), cystic hygroma, hydrops fetalis, pleural effusion, polyhydramnios, CHD and renal abnormalities. $^{20-24}$ The first prenatal DNA diagnosis of NS in a fetus with massive cystic hygroma, pleural effusion and ascites showed a mutation in the PTPN11 gene. ${ }^{25}$ Lee et $a^{26}$ performed a retrospective review of prenatal PTPN11 testing. The two most common indications for testing in this study were increased NT (44\%) and cystic hygroma (48\%). PTPN11 mutations were identified in $9 \%$ of fetuses ( 2 and $16 \%$ of fetuses with increased NT and cystic hygroma, respectively). In a prospective DNA diagnostic study on fetuses with a normal karyotype and an increased NT, we previously identified a de novo mutation rate of $15.8 \%$ (3/19 fetuses) by parallel sequencing of PTPN11 and KRAS. ${ }^{27}$

In the present study, we investigated the DNA of 56 additional fetuses with a normal karyotype and one or more abnormal ultrasound findings for a mutation in one or more of the NS genes in a diagnostic setting. Parallel sequencing of PTPN11, KRAS, SOS1 and RAF1 was offered, as these are the most frequent mutated genes in patients diagnosed with NS after birth. The actual number of genes tested in each fetus depended on the amount of DNA available for testing (chorionic villi or amniotic fluid, cultured or uncultured cells). In an attempt to define whether parallel sequencing of these four genes revealed the highest mutation frequency in fetuses with an abnormal ultrasound, we investigated in a second anonymized study the DNA (amplified by whole genome amplification to allow a sufficient amount of DNA) of 60 other fetuses with increased NT, hydrops fetalis and/or CHD and a normal karyotype, for mutations in 10 genes of the RAS-MAPK pathway.

${ }^{1}$ Department of Paediatrics, Radboud University Nijmegen Medical Centre, Nijmegen, The Netherlands; ${ }^{2}$ Department of Human Genetics, Radboud University Nijmegen Medical Centre, Nijmegen, The Netherlands; ${ }^{3}$ Department of Clinical Genetics, VU University Medical Centre, Amsterdam, The Netherlands; ${ }^{4}$ Department of Clinical Genetics, Erasmus Medical Centre, Rotterdam, The Netherlands; ${ }^{5}$ Department of Clinical Genetics, Academic Medical Centre, Amsterdam, The Netherlands

*Correspondence: Dr HG Yntema, Department of Human Genetics, Radboud University Nijmegen Medical Centre, P.O. Box 9101, 6500 HB Nijmegen, The Netherlands. Tel: +31 24361 3799; Fax: +31 24361 6658; E-mail: h.yntema@gen.umcn.nl

Received 25 June 2012; revised 28 November 2012; accepted 28 November 2012; published online 16 January 2013 
The aim of this study is to provide a protocol for prenatal NS testing, to serve as a useful aid to facilitate parental counseling and targeted DNA testing.

\section{MATERIALS AND METHODS}

\section{Patients}

The first, diagnostic, study group consisted of 75 fetuses with a normal karyotype and one or more abnormal ultrasound findings. This group contains all fetuses sent to our laboratory from different clinical genetics centers in the Netherlands for a period of 2 years. Part of the positive cases have been described in case reports. ${ }^{24,27}$ Ultrasound findings considered as indication for prenatal sequencing were increased NT (greater than the 95th percentile (p95)), cystic hygroma, distended JLS, ascites, hydrops fetalis, pleural effusion, polyhydramnios, CHD and renal abnormalities.

From all mutation-negative cases the ultrasound findings provided by the referring physician were marked, and ultrasound findings that were not mentioned were regarded not to be present. From all the mutation-positive cases the applicants were asked to deliver detailed information about gestational age (GA) and corresponding ultrasound findings. Blood of both parents was available for testing of detected mutations and variants.

The second, anonymized, study group consisted of 60 other fetuses with increased NT, hydrops fetalis and/or CHD and a normal karyotype. Medical records of these cases were reviewed before anonymizing the samples. Because of the anonymous design of the study, parents could not be tested and results were not communicated to the parents.

\section{Sequence analysis}

In the diagnostic study group, parallel sequencing of the coding regions and splice sites of PTPN11, KRAS, SOS1 and RAF1 was performed. The number of genes tested depended on the amount of DNA available for testing (chorionic villi or amniotic fluid, cultured or uncultured cells) and the GA of the pregnancy. In 15 fetuses only PTPN11 was tested, 9 fetuses were tested for PTPN11 and KRAS, 11 fetuses were tested for PTPN11, KRAS, and SOS1. In 40 fetuses all four genes were analyzed. The order of genes tested in case not enough DNA was available (PTPN11, KRAS, SOS1, RAF1) is based on the reported mutation frequency in postnatally diagnosed NS cases.

In the anonymized study group, $10 \mathrm{ng}$ of fetal DNA was amplified using the Illustra Genomiphi V2 DNA amplification kit (GE Healthcare, Piscataway, NJ, USA), according to the manufacturer's protocol. The coding regions and splice sites of 10 genes were sequenced: PTPN11, KRAS, RAF1, SOS1, BRAF, NRAS, SHOC2, MAP2K1, MAP2K2, and HRAS. Mutations were confirmed on the unamplified fetal material. Primers and $\mathrm{PCR} /$ sequencing conditions are available upon request.

\section{Interpretation of sequence variants}

For all detected variants that were not previously described in literature, an insilico-based method (Alamut software version 2.0, Interaction Biosoftware,
Rouen, France) was used to assess the effect of the mutation. Parameters used in this program include the Grantham score, SIFT and PolyPhen analysis, PhyloP score and analysis of frequency of the mutation in the population.

\section{Statistical analysis}

The data were collected in SPSS 16.0. For statistical analysis we used the Student's $t$-test and the Fischer's Exact test. A statistically significant two-sided threshold was set at $P<0.05$. Because of the small number of fetuses also descriptive analysis was performed.

\section{RESULTS}

\section{Diagnostic study group}

The diagnostic study group included 75 fetuses with a normal karyotype and abnormal ultrasound findings, described in NS.

Table 1 shows the prenatal ultrasound findings in the total group and classified by the presence or absence of a mutation. The most frequently identified prenatal characteristics are increased NT $(n=50$; $66.7 \%)$, cystic hygroma $(n=17 ; 22.7 \%)$, cardiac anomalies and hydrops fetalis (each $n=15 ; 20.0 \%)$, distended JLS ( $n=12 ; 16.0 \%)$, hydrothorax $(n=9 ; 12.0 \%)$, renal anomalies $(n=7 ; 9.3 \%)$, polyhydramnios $(n=3 ; 4.0 \%)$ and ascites $(n=1 ; 1.3 \%)$. No postnatal information of the mutation-negative cases is present. However, we never received a request for testing of the remaining NS genes once the baby was born, suggesting that no NS-specific features were present. However, it cannot be excluded that part of the pregnancies have been terminated because of the abnormalities seen on the ultrasound.

In $13 / 75(17.3 \%)$ fetuses a mutation was detected. Table 2 shows their pre- and postnatal clinical characteristics. The mutations and clinical features of four of these fetuses have also been described elsewhere; case 1 has been described by Bakker et al ${ }^{24}$ and cases 9, 12 and 13 have been described by Houweling et al. ${ }^{27}$ Nine fetuses had a de novo mutation in PTPN11, three in RAF1 and one in KRAS. Eight of the 12 different mutations detected in this study have been described earlier in postnatally identified NS patients: PTPN11; c. $174 \mathrm{C}>\mathrm{G}$ (p. (Asn58Lys)), ${ }^{28}$ c.182A $>$ G (p. (Asp61Gly)), ${ }^{4}$ c. $184 \mathrm{~T}>\mathrm{G}$ (p. (Tyr62Asp)), ${ }^{5} \quad$ c.205G $>C \quad$ (p. (Glu69Gln)), ${ }^{28} \quad$ c,417G $>C$ (p.(Glu139Asp)), ${ }^{5}$ and c.854T $>\mathrm{C} \quad$ (p.(Phe285Ser)), ${ }^{5}$ RAF1 c.770C $>$ T (p. (Ser257Leu) $),{ }^{10}$ and KRAS c.173C $>$ T (p. $($ Thr58Ile) $) .{ }^{6}$ One mutation has been previously described in a patient with the clinical diagnosis of LEOPARD syndrome: PTPN11 (c.1381G > A, p.(Ala461Thr)). ${ }^{29}$ The remaining three mutations had not been described in literature before the detection in this study: RAF1 (c.775T >C, p.(Ser259Pro)), PTPN11 (c.181G >C,

Table 1 Prenatal findings of 75 fetuses with a normal karyotype

\begin{tabular}{|c|c|c|c|c|}
\hline Findings & Total group $(\mathrm{n}=75)$ & Mutation-positive group $(\mathrm{n}=13)(\%)$ & Mutation-negative group $(\mathrm{n}=62)(\%)$ & $P$-value \\
\hline Increased NT (\%) & $50 / 75(66.7)$ & $13 / 13(100)$ & $37 / 62(59.7)$ & $0.003^{a}$ \\
\hline Mean NT $(\mathrm{mm})$ at $11-14$ weeks & $7.3(3.6-14)$ & $8.0(4.2-14)$ & $6.5(3.6-11.9)$ & $0.854^{b}$ \\
\hline Cystic hygroma & $17 / 75(22.7)$ & 4/13 (30.8) & $13 / 62(21.0)$ & $0.475^{a}$ \\
\hline Distended JLS & $12 / 75(16.0)$ & $7 / 13(53.8)$ & $5 / 62(8.1)$ & $0.000^{a}$ \\
\hline Ascites & $1 / 75(1.3)$ & $1 / 13(7.7)$ & $0 / 62(0.0)$ & $0.173^{a}$ \\
\hline Hydrothorax & $9 / 75(12.0)$ & $7 / 13(53.8)$ & $2 / 62(3.2)$ & $0.000^{a}$ \\
\hline Cardiac anomalies & $15 / 75(20.0)$ & $5 / 13(38.5)$ & $10 / 62(16.1)$ & $0.120^{a}$ \\
\hline Renal anomalies & $7 / 75(9.3)$ & $6 / 13(46.2)$ & $1 / 62(1.6)$ & $0.000^{a}$ \\
\hline Hydrops fetalis & $15 / 75(20.0)$ & $4 / 13(30.8)$ & $11 / 62(17.7)$ & $0.279^{a}$ \\
\hline Polyhydramnion & $3 / 75(4.0)$ & $3 / 13(23.1)$ & $0 / 62(0.0)$ & $0.004^{a}$ \\
\hline
\end{tabular}

Abbreviations: JLS, jugular lymphatic sacs; NT, nuchal translucency.

aFisher's Exact test.

bStudent's $t$-test. 
p.(Asp61His) and PTPN11 (c.227A $>$ T, p.(Glu76Val)). These mutations were considered to be pathogenic as the mutations were not present in both the parents. Furthermore, they affect highly conserved amino acids, and in silico analysis (Alamut software) predicts a pathogenic effect. Additionally, further evidence for pathogenicity of these mutations is given by the fact that the c.181G > C and c.227A > T mutations in PTPN11 were detected as somatic events in malignancies. ${ }^{30}$ As the Ser 259 residue is critical for autoinhibition of RAF1, mutations affecting this residue facilitate binding of RAF1 to GTP-bound RAS and its activation. ${ }^{9}$

Twelve fetuses with a mutation had an increased NT with a mean NT of $8 \mathrm{~mm}$ at GA of 11-14 weeks (range $4.2-14 \mathrm{~mm}$ ). The NT value of case 6 was not measured at this term. Apart from the increased NT, all mutation-positive fetuses had one or more other sonographic abnormalities. These were, in order of frequency: distended JLS $(n=7 ; 53.8 \%)$, hydrothorax $(n=7 ; 53.8 \%)$, renal anomalies $(n=6 ; 46.2 \%)$, cardiac anomalies $(n=5 ; 38.5 \%)$, cystic hygroma $(n=4 ; 30.8 \%)$, hydrops fetalis $(n=4 ; 30.8 \%)$, polyhydramnios $(n=3 ; 23.1 \%)$ and ascites $(n=1 ; 7.7 \%)$. In three fetuses limb anomalies were described (syndactyly of the 4th and 5th finger, clubfeet and short femura). In five fetuses, facial characteristics such as low-set ears, uplifted earlobes, small nose, sloping forehead and brachycephaly were noted. Twelve of 13 pregnancies were terminated after extensive counseling. One woman had a planned caesarian section at GA 32 weeks, but the neonate deceased suddenly 1 day post partum.

An increased NT, distended JLS, hydrothorax, renal anomalies and polyhydramnios were significantly more common in the mutationpositive group (Table 1). The mean NT at GA 11-14 weeks was $8 \mathrm{~mm}$ in the mutation-positive group versus $6.5 \mathrm{~mm}$ in the mutationnegative group, which is not statistically significant $(P=0.854)$. In the mutation-positive group a tendency of increasing NT with advancing GA was observed in the group as a whole (Figure 1). This trend is not seen in the mutation-negative group.

\section{Anonymized study group}

Our second study group consisted of anonymized DNA from 60 fetuses with abnormal prenatal ultrasound findings including increased NT, hydrops fetalis and/or cardiac anomalies, referred to our department for routine chromosomal analysis.

Indications for karyotyping were increased NT in 17/60 fetuses $(28.3 \%)$, cardiac anomaly in $35 / 60(58.3 \%)$, hydrops fetalis in $7 / 60$ $(11.7 \%)$ and in one fetus both a cardiac anomaly and hydrops fetalis were indications for testing (1.7\%). Other characteristic ultrasound findings were cystic hygroma/distended JLS $(n=2 ; 3.3 \%)$, ascites $(n=5 ; 8.3 \%)$, hydrothorax $(n=5 ; 8.3 \%)$, renal anomalies $(n=3$; $5.0 \%)$ and polyhydramnios $(n=3 ; 5.0 \%)$ (Table 3 ). All karyotypes were normal.

In five fetuses $(8.3 \%)$ a mutation in one of the 10 NS genes was found. Besides the previously described pathogenic mutation c.854T $>$ C (p.(Phe285Ser)) in PTPN11 $\left(^{5}\right)$, four unclassified variants were identified: PTPN11 (c.430C $>\mathrm{T}, \mathrm{p}$.(Pro144Ser)), RAF1 (c.935T > G, p.(Val312Gly)), BRAF (c.1150A > G, p.(Arg384Gly)) and MAP2K1 (c.1039G > A, p.(Ala347Thr)). Although these variants have not been described before and de novo occurrence could not be tested, we hypothesize that these mutations are likely to be causative as the in silico analysis predicts a deleterious effect. Although the frequency of these variants has not been tested in healthy controls, the absence of these mutations in postnatally tested cases in our laboratory $(\sim 100$ for RAF1, $\sim 150$ for BRAF and MAP2K1, and $\sim 1700$ for PTPN11), and in public databases (NHLBI GO Exome Sequencing project, and
dbSNP XML build 135), supports the fact that these changes are not frequently identified polymorphisms. However, in the absence of parental DNA, further evidence on the pathogenicity of these unclassified variants can only be generated by biochemical and/or functional characterization.

To provide further evidence for the involvement of $B R A F$ and MAP2K1 mutations (that were not tested in the diagnostic study group), we anonymized 27 DNA samples (all samples with sufficient DNA left) from that group and sequenced both genes. One sample contained a mutation in the MAP2K1 gene (c.383G>A, p.(Gly128Asp)). Because of the anonimization of the samples, no clinical features of the fetus can be described, and the parents could not be tested. The exact mutation has not been described in literature, but is regarded to be pathogenic as a mutation of the same amino acid (p.Gly128Val)) has been reported in a patient with CFC syndrome. ${ }^{31}$

No significant differences in clinical characteristics were found between the mutation-positive and negative fetuses in this study group.

\section{DISCUSSION}

Analysis of the diagnostic study group consisting of 75 fetuses with a normal karyotype and one or more abnormal ultrasound findings suggestive for NS syndrome revealed a de novo mutation in 13 fetuses in one of the four tested genes known to be related to NS (PTPN11, KRAS, SOS1 and RAF1). This corresponds to a positive test rate of $17.3 \%$. As part of this cohort (19 fetuses sent in by one of the Dutch medical centers) has previously been described by Houweling et al, ${ }^{27}$ we also have calculated the mutation frequency in the undescribed cases. In the additional 56 fetuses, 10 mutations have been identified, which corresponds to a mutation frequency of $17.9 \%$. This slightly higher percentage is probably explained by the fact that in the first 19 cases only two genes have been tested. As no pathogenic mutations have been detected in the SOS1 gene, analysis of three genes (PTPN11, $K R A S$ and $R A F 1$ ) would have revealed the same mutation frequency. The fact that no SOS1 mutations have been detected, although SOS1 mutations underlie twice as much NS as do RAF1 mutations, is likely explained by the fact that the milder SOS1-related NS may be difficult to detect in utero with ultrasound. Lee et $a l^{26}$ analyzed 134 fetuses with one or more sonographic findings suggestive of NS for PTPN11 mutations only and found a positive test rate of $9 \%$. In our previous study parallel testing of PTPN11 and KRAS in fetuses with a normal karyotype and an increased NT showed a mutation frequency of $15.8 \%{ }^{27}$ The lower-positive test rate reported by Lee et al ${ }^{26}$ might be due to the fact that only PTPN11 was tested.

In the present study, prenatal testing of PTPN11, KRAS, SOS1 and $R A F 1$ was offered to parents carrying a fetus with a normal karyotype and ultrasound abnormalities as seen in NS. The actual number of genes tested depended on the amount of DNA available for testing. The prenatal findings of the mutation-positive fetuses found in our diagnostic study group were increased NT, distended JLS, hydrothorax, renal anomalies, cardiac anomalies, cystic hygroma, hydrops fetalis, polyhydramnios and ascites. An increased NT, distended JLS, hydrothorax, renal anomalies and polyhydramnios were significant more common in mutation-positive fetuses. However, features in the mutation-negative fetuses that are not specifically mentioned were considered not to be present. Bakker et al ${ }^{24}$ reviewed the literature on prenatal findings in NS and mentioned increased NT/cystic hygroma (35.7\%), distended JLS (16.7\%), hydrothorax (40.5\%), renal anomalies (23.8\%), cardiac anomalies $(38.1 \%)$, scalp/skin edema (33\%), polyhydramnios (50\%) and ascites (14.3\%). Baldassarre 
Table 2 Prenatal and postnatal findings of 13 mutation-positive fetuses in the diagnostic study group

\begin{tabular}{|c|c|c|c|c|c|c|c|}
\hline $\begin{array}{l}\text { Prenatal and Post- } \\
\text { natal findings }\end{array}$ & $\begin{array}{l}\text { Case } 1 \text { (Bakker } \\
\text { et } \mathrm{al}^{24} \text { ) }\end{array}$ & Case 2 & Case 3 & Case 4 & Case 5 & Case 6 & Case 7 \\
\hline DNA mutation & $\begin{array}{l}\text { RAF1 c. } 770 \mathrm{C}>\mathrm{T} \\
\text { (p.Ser257Leu) } \\
\text { de novo }\end{array}$ & $\begin{array}{l}\text { PTPN11 } \\
\text { c.174C>G } \\
\text { (p.Asn58Lys) } \\
\text { de novo }\end{array}$ & $\begin{array}{l}\text { RAF1 c. } 770 \mathrm{C}>\mathrm{T} \\
\text { (p.Ser257Leu) } \\
\text { de novo }\end{array}$ & $\begin{array}{l}\text { RAF1 c.775T>C } \\
\text { (p.Ser259Pro) } \\
\text { de novo }\end{array}$ & $\begin{array}{l}\text { PTPN11 } \\
\text { c.1381G >A } \\
\text { (p.Ala461Thr) } \\
\text { de novo }\end{array}$ & $\begin{array}{l}\text { PTPN11 } \\
\text { c.182A>G } \\
\text { (p.Asp61Gly) } \\
\text { de novo }\end{array}$ & $\begin{array}{l}\text { PTPN11 } \\
\text { c.854T >C } \\
\text { (p.Phe285Ser) } \\
\text { de novo }\end{array}$ \\
\hline \multicolumn{8}{|l|}{ Prenatal findings } \\
\hline Increased NT (mm) & 4.4 & 4.2 & 10.0 & 7.6 & $6.5-11.2$ & Unknown & 7.8 \\
\hline Cystic hygroma & No & No & No & Yes & No & Yes & No \\
\hline Distended JLS & No & No & Yes & No & No & No & Yes $(8.5-14 \mathrm{~mm})$ \\
\hline Ascites & No & No & Yes & No & No & No & No \\
\hline Hydrothorax & No & $\begin{array}{l}\text { Yes } \\
\text { (right side) }\end{array}$ & $\begin{array}{l}\text { Yes } \\
\text { (both sides) }\end{array}$ & $\begin{array}{l}\text { Yes } \\
\text { (both sides) }\end{array}$ & $\begin{array}{l}\text { Yes } \\
\text { (left side) }\end{array}$ & $\begin{array}{l}\text { Yes } \\
\text { (right side) }\end{array}$ & No \\
\hline Hydrops fetalis & No & No & Yes & Yes & Yes & No & No \\
\hline Polyhydramnios & No & Yes & No & Yes & No & Yes & No \\
\hline Cardiovascular & Yes & Yes & No & No & No & No & Yes \\
\hline Anomalies & $\begin{array}{l}\text { Mild TR, malalign- } \\
\text { ment VSD, heart } \\
\text { axis deviation, RV } \\
\text { dysfunction, PE }\end{array}$ & $\begin{array}{l}\text { Ductus venosus } \\
\text { agenesis }\end{array}$ & & & & & $\begin{array}{l}\text { Hypoplastic left } \\
\text { heart, retrograde } \\
\text { flow aorta }\end{array}$ \\
\hline Renal anomalies & $\begin{array}{l}\text { Yes } \\
\text { Bilateral pyelectasis }\end{array}$ & No & $\begin{array}{l}\text { Yes } \\
\text { Bilateral } \\
\text { echogenicity }\end{array}$ & $\begin{array}{l}\text { Yes } \\
\text { Hydronephrosis }\end{array}$ & No & $\begin{array}{l}\text { Yes } \\
\text { Unilateral } \\
\text { pyelectasis }\end{array}$ & No \\
\hline Facial features & $\begin{array}{l}\text { Yes } \\
\text { Low-set ears with } \\
\text { uplifted earlobes, } \\
\text { small nose, sloping } \\
\text { forehead, } \\
\text { brachycephaly }\end{array}$ & $\begin{array}{l}\text { Yes } \\
\text { Mild ptosis }\end{array}$ & & & & & No \\
\hline Limb anomalies & & No & & $\begin{array}{l}\text { Yes } \\
\text { Clubfeet }\end{array}$ & & $\begin{array}{l}\text { Yes } \\
\text { Syndactyly 4th and } \\
5 \text { th finger }\end{array}$ & No \\
\hline $\begin{array}{l}\text { Indication for } \\
\text { testing }\end{array}$ & $\begin{array}{l}\text { Increased NT, facial } \\
\text { features }\end{array}$ & $\begin{array}{l}\text { Increased NT, } \\
\text { ductus venosus } \\
\text { agenesis }\end{array}$ & Increased NT & Increased NT & Increased NT & Increased NT & $\begin{array}{l}\text { Increased NT, } \\
\text { distended JLS and } \\
\text { hypoplastic left } \\
\text { heart }\end{array}$ \\
\hline Pregnancy course & TOP GA $22+1$ & $\begin{array}{l}\text { Planned sectio } \\
\text { Caesarea at } \\
\text { GA } 32 \text {, deceased } \\
\text { suddenly } 1 \text { day } \\
\text { post partum }\end{array}$ & TOP GA $17+3$ & TOP GA $20+2$ & TOP GA $16+4$ & TOP GA $23+3$ & TOP GA $16+1$ \\
\hline \multicolumn{8}{|l|}{ Postnatal findings } \\
\hline Facial features & $\begin{array}{l}\text { Low-set posteriorly } \\
\text { angulated ears, } \\
\text { broad nose, } \\
\text { brachycephaly }\end{array}$ & $\begin{array}{l}\text { Downslanted pal- } \\
\text { pebral } \\
\text { fissures, hypertelor- } \\
\text { ism, low-set poster- } \\
\text { iorly angulated ears, } \\
\text { broad neck, low } \\
\text { anterior hairline }\end{array}$ & $\begin{array}{l}\text { Deep nasal bridge, } \\
\text { hypertelorism, low- } \\
\text { set posteriorly } \\
\text { angulated ears, } \\
\text { anteverted nares, } \\
\text { broad mouth, long } \\
\text { philtrum }\end{array}$ & Low-set ears & $\begin{array}{l}\text { Short nose, ante- } \\
\text { verted nares, low- } \\
\text { set posteriorly } \\
\text { angulated ears }\end{array}$ & & $\begin{array}{l}\text { Low-set ears, } \\
\text { retrognathia }\end{array}$ \\
\hline $\begin{array}{l}\text { Cardiovascular } \\
\text { anomalies }\end{array}$ & $\begin{array}{l}\text { Subaortal stenosis, } \\
\text { LVH, perimembrous } \\
\text { VSD }\end{array}$ & No & & $\begin{array}{l}\text { Deep interventricu- } \\
\text { lar fissure externally }\end{array}$ & & & $\begin{array}{l}\text { HLH ASD type II, } \\
\text { perimembranous } \\
\text { VSD, mitral steno- } \\
\text { sis, aortic stenosis, } \\
\text { hypoplasia aortic } \\
\text { arch }\end{array}$ \\
\hline
\end{tabular}


Table 2 (Continued)

\begin{tabular}{|c|c|c|c|c|c|c|}
\hline $\begin{array}{l}\text { Prenatal and } \\
\text { Postnatal } \\
\text { findings }\end{array}$ & Case 8 & $\begin{array}{l}\text { Case } 9 \text { (Houweling } \\
\text { et } \mathrm{al}^{27} \text { ) }\end{array}$ & Case 10 & Case 11 & $\begin{array}{l}\text { Case } 12 \\
\text { (Houweling } \\
\text { et } \mathrm{al}^{27} \text { ) }\end{array}$ & Case 13 (Houweling et $\mathrm{al}^{27}$ ) \\
\hline $\begin{array}{l}\text { Renal } \\
\text { anomalies }\end{array}$ & & No & & & & No \\
\hline Other features & $\begin{array}{l}\text { Redundant nuchal } \\
\text { skin, generalized skin } \\
\text { edema }\end{array}$ & $\begin{array}{l}\text { Severe hydrops, } \\
\text { brachydactyly, } \\
\text { virilized genital }\end{array}$ & & $\begin{array}{l}\text { Severe hydrops } \\
\text { clubfeet }\end{array}$ & & Hygroma colli \\
\hline DNA Mutation & $\begin{array}{l}\text { PTPN11 c. } 227 \mathrm{~A}>\mathrm{T} \\
\text { (p.Glu76Val) } \\
\text { de novo }\end{array}$ & $\begin{array}{l}\text { KRAS c. } 173 \mathrm{C}>\mathrm{T} \\
\text { (p.Thr58lle) de novo }\end{array}$ & $\begin{array}{l}\text { PTPN11 c. } 184 T>G \\
\text { (p.Tyr62Asp) de } \\
\text { novo }\end{array}$ & $\begin{array}{l}\text { PTPN11 c. } 205 \mathrm{G}>\mathrm{C} \\
\text { (p.Glu69GIn) de novo }\end{array}$ & $\begin{array}{l}\text { PTPN11 } \\
\text { c.417G >C } \\
\text { (p.Glu139Asp) } \\
\text { de novo }\end{array}$ & $\begin{array}{l}\text { PTPN11 c. } 181 \mathrm{G}>\mathrm{C} \\
\text { (p.Asp61His) de novo }\end{array}$ \\
\hline \multicolumn{7}{|l|}{ Prenatal findings } \\
\hline $\begin{array}{l}\text { Increased NT } \\
(\mathrm{mm})\end{array}$ & 11 & 14 & 5.1 & 8.5 & 5.2 & 8.2 \\
\hline Cystic hygroma & Yes & No & No & Yes $(6.9 \mathrm{~mm})$ & No & No \\
\hline Distended JLS & No & Yes & Yes $(7.1 \times 8.7 \mathrm{~mm})$ & Yes & Yes & Yes \\
\hline Ascites & No & No & No & No & No & No \\
\hline Hydrothorax & Yes (left side) & Yes (both sides) & No & No & No & No \\
\hline Hydrops fetalis & Yes & No & No & No & No & No \\
\hline Polyhydramnios & No & No & No & No & No & No \\
\hline $\begin{array}{l}\text { Cardiac } \\
\text { anomalies }\end{array}$ & No & No & No & $\begin{array}{l}\text { Yes } \\
\text { Hypoplastic right heart } \\
\text { with small arteriae } \\
\text { pulmonalis }\end{array}$ & No & $\begin{array}{l}\text { Yes } \\
\text { Pericardial effusion, AVSD }\end{array}$ \\
\hline $\begin{array}{l}\text { Renal } \\
\text { anomalies }\end{array}$ & No & $\begin{array}{l}\text { Yes } \\
\text { Bilateral pyelectasis } \\
\text { (right } 9.6 \mathrm{~mm} \text {, left } \\
7.7 \mathrm{~mm} \text { ) }\end{array}$ & No & No & No & $\begin{array}{l}\text { Yes } \\
\text { Bilateral pyelectasis }\end{array}$ \\
\hline Facial features & $\begin{array}{l}\text { Yes } \\
\text { Unclassified because } \\
\text { of edema }\end{array}$ & $\begin{array}{l}\text { Yes } \\
\text { Low-set ears }\end{array}$ & & $\begin{array}{l}\text { Yes } \\
\text { Low-set ears }\end{array}$ & No & \\
\hline $\begin{array}{l}\text { Limb } \\
\text { anomalies }\end{array}$ & No & & & & & $\begin{array}{l}\text { Yes } \\
\text { Short femura }(<p 5)\end{array}$ \\
\hline $\begin{array}{l}\text { Indication for } \\
\text { testing }\end{array}$ & Hydrops fetalis & Increased NT & Increased NT & Increased NT & $\begin{array}{l}\text { Increased NT, } \\
\text { distended JLS }\end{array}$ & Increased NT, AVSD, short femura \\
\hline $\begin{array}{l}\text { Pregnancy } \\
\text { course }\end{array}$ & TOP GA $17+4$ & TOP GA $22+2$ & TOP & TOP GA $21+5$ & TOP GA $23+5$ & TOP GA $16+0$ \\
\hline \multicolumn{7}{|c|}{ Postnatal findings } \\
\hline Facial features & $\begin{array}{l}\text { Extremely low-set } \\
\text { posteriorly } \\
\text { angulated ears, } \\
\text { hypertelorism }\end{array}$ & $\begin{array}{l}\text { Hypertelorism, } \\
\text { low-set ears }\end{array}$ & & & $\begin{array}{l}\text { Hypertelorism, } \\
\text { low-set left ear }\end{array}$ & $\begin{array}{l}\text { Low-set posteriorly angulated } \\
\text { ears, hypertelorism, webbing of } \\
\text { the neck }\end{array}$ \\
\hline $\begin{array}{l}\text { Cardiac } \\
\text { anomalies }\end{array}$ & No & Hypertrophy & & & $\begin{array}{l}\text { Hypertrophy } \\
\text { interventricular } \\
\text { septum }\end{array}$ & Complete AVSD \\
\hline $\begin{array}{l}\text { Renal } \\
\text { anomalies }\end{array}$ & No & Bilateral pyelectasis & & & & \\
\hline Other features & Severe skin edema & Nuchal edema & & & $\begin{array}{l}\text { Loose nuchal } \\
\text { skin }\end{array}$ & \\
\hline
\end{tabular}

Abbreviations: AVSD, atrio ventricular septal defect; GA, gestational age; HLH, hypoplastic left heart; JLS, jugular lymphatic sacs; LVH, left ventricular hypertrophy; NT, nuchal translucency; PE, pericardial effusion; RV, right ventricle; TOP, termination of pregnancy; TR, tricuspid regurgitation; VSD, ventricular septum defect; * increased NT: measured at 11-14 weeks.

et $a l^{32}$ found most frequently polyhydramnios (38.3\%) and increased NT (41\%). The two most commonly reported indications for prenatal testing reported by Lee et $a^{26}$ were increased NT (44\%) and cystic hygroma (48\%). In our study mutation-positive fetuses showed an increased NT and at least one of the following additional features: polyhydramnios, hydrops fetalis, renal anomalies, distended JLS, hydrothorax, cardiac anomalies, cystic hygroma or ascites. Therefore, we recommend these characteristics as important indications for prenatal NS testing. Future studies should reveal whether testing of the NS genes in fetuses with isolated NT is worthwile. 


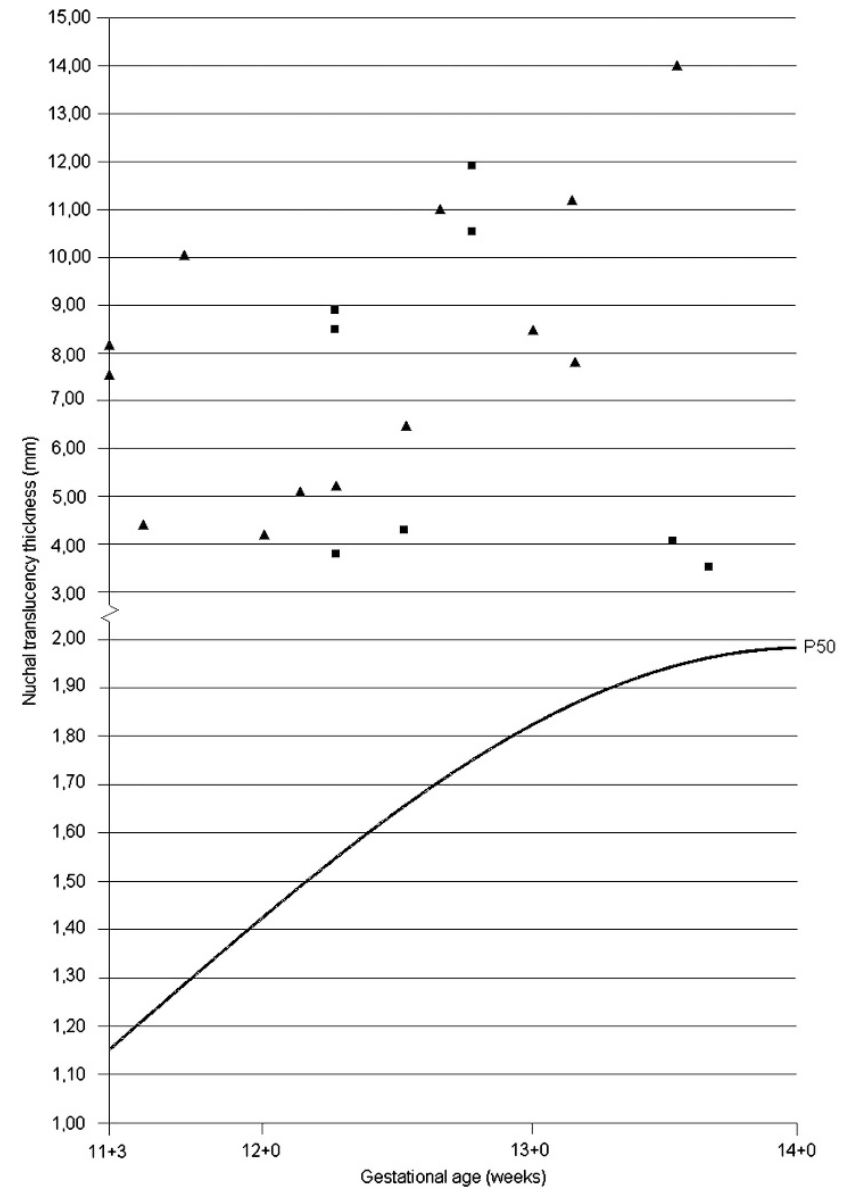

Figure 1 NT values of mutation-positive cases $(n=13)$ and mutationnegative cases $(n=8)$ from the diagnostic study group, according to GA. Only those cases for which NT values between 11-14 weeks of gestation were available, are shown. Mutation-positive cases are depicted by gray dots; mutation-negative cases are depicted by black dots.

Table 3 Prenatal findings in 60 anonymous fetuses with a normal karyotype

\begin{tabular}{|c|c|c|c|c|c|c|c|}
\hline \multirow[b]{2}{*}{ Prenatal findings } & \multicolumn{2}{|c|}{ Total group } & \multicolumn{2}{|c|}{$\begin{array}{c}\text { Mutation- } \\
\text { positive group }\end{array}$} & \multicolumn{2}{|c|}{$\begin{array}{c}\text { Mutation- } \\
\text { negative group }\end{array}$} & \multirow[b]{2}{*}{$P$-value } \\
\hline & $(n=60)$ & (\%) & $(n=5)$ & (\%) & $(n=55)$ & (\%) & \\
\hline \multicolumn{8}{|c|}{ Indication DNA research } \\
\hline $\begin{array}{l}\text { Increased NT } \\
\text { (>95th centile) }\end{array}$ & $17 / 60$ & $(28.3)$ & $2 / 5$ & $(40.0)$ & $15 / 55$ & $(27.3)$ & 0.616 \\
\hline Hydrops fetalis & $8 / 60$ & $(13.3)$ & $1 / 5$ & $(20.0)$ & $7 / 55$ & $(12.7)$ & 0.524 \\
\hline Cardiac anomaly & $36 / 60$ & $(60.0)$ & $2 / 5$ & $(40.0)$ & $34 / 55$ & $(61.8)$ & 0.380 \\
\hline \multicolumn{8}{|l|}{ Other findings } \\
\hline $\begin{array}{l}\text { Cystic hygroma/ } \\
\text { distended JLS }\end{array}$ & $2 / 60$ & (3.3) & $1 / 5$ & $(20.0)$ & $1 / 55$ & (1.8) & 0.161 \\
\hline Ascites & $5 / 60$ & (8.3) & $0 / 5$ & (0) & $5 / 55$ & $(9.1)$ & 1.000 \\
\hline Hydrothorax & $5 / 60$ & (8.3) & $1 / 5$ & $(20.0)$ & $4 / 55$ & (7.3) & 0.363 \\
\hline Renal anomaly & $3 / 60$ & $(5.0)$ & $0 / 5$ & (0) & $3 / 55$ & (5.5) & 1.000 \\
\hline Polyhydramnion & $3 / 60$ & (5.0) & $0 / 5$ & (0) & $3 / 55$ & $(5.5)$ & 1.000 \\
\hline
\end{tabular}

Abbreviations: DNA, deoxyribonucleic acid; JLS, jugular lymphatic sacs; NT, nuchal translucency.

aFisher's Exact test.
In the second study group of 60 anonymized fetuses with abnormal prenatal ultrasound findings, we detected a potential-positive test rate of $8.3 \%$. No significant differences were found between mutationpositive and negative fetuses regarding prenatal findings. These two observations are different from the results in the first study group. However, a more detailed analysis of the difference in occurrence of features between the two cohorts is not possible, because the inclusion criteria in the two study groups are not the same. Furthermore, because of the anonymous nature of the second group the description of sonographic abnormalities on the request form might not be complete.

The mutation rate could actually by higher than $8.3 \%$, as false negative results cannot be ruled out. Both preferential amplification and allele dropout are known problems accompanying whole genome amplification, ${ }^{33}$ as all mutations have been verified on the original (unamplified) DNA, false-positive cases have been excluded. The lower-positive test rate can also be explained by the fact that a cardiac anomaly was the most common (60\%) indication for testing in this study group. Two out of five fetuses with a mutation had a cardiac anomaly (40\%). The findings of both the diagnostic and the anonymized study group support the fact that cardiac anomalies alone will not differentiate between the presence or absence of a mutation in one of the NS genes and should thus not be the main indication for further investigation. Additionally, it is notable that cardiac anomalies are less common in our positive fetuses $38.5 \%$ in the diagnostic study group and $40.0 \%$ in the anonymized study group) compared with the general NS population (66-87\%)., ${ }^{1,34-36}$ Also Menashe et $a \mathbb{R}^{22}$ noted that heart malformations were evident prenatally only in a small group of NS patients (27\%), which could be explained by the fact that the most common heart malformations, pulmonary stenosis and hypertrophic cardiomyopathy, develop during pregnancy or early childhood. This observation suggests that the cardiac anomaly in NS is a cryptic condition in early gestation and has an evolving phenotype in utero and in postnatal life. ${ }^{37}$

Interestingly, we only know of an increased NT in two of the mutation-positive fetuses from the anonymized study group. The anonymous nature of this study group did not allow us to discriminate between the possibilities that in the other three mutation-positive fetuses from this group an increased NT was not present but not mentioned, or was not present at all. Therefore, it cannot be ruled out that mutations in the NS genes are found in fetuses with a normal NT.

Although we are aware of the fact that prenatal testing for NS and the possibility to terminate a pregnancy is not common in all countries, based on our findings in the positive fetuses from the first cohort and current literature, we would recommend prenatal testing of NS genes when an increased NT is seen in combination with at least one of the following additional features: polyhydramnios, hydrops fetalis, renal anomalies, distended JLS, hydrothorax, cardiac anomalies, cystic hygroma or ascites. When chromosomal analysis has revealed a normal karyotype, parents should be referred to a clinical geneticist for counseling and an ultrasound examination at 16 weeks. If thereafter genetic testing for NS is indicated, it is advised to collect parental blood simultaneously with the fetal sample, as in case of the identification of a mutation in the fetus, the parental DNA can immediately be tested for de novo occurrence. This saves precious time and limits the uncertainty about pathogenicity of the mutation. The recommended genes for testing are PTPN11, RAF1 and KRAS. If sufficient time and DNA is left, mutation analysis of BRAF and MAP2K1 should be considered. For optimal decision-making by the parents, the results of the tests performed should be disclosed when the option of terminating the 
pregnancy (in the Netherlands at 24 weeks of gestation) is still open. We recently adapted our DNA diagnostic protocol according to the criteria described in this paper. Although parallel sequencing of these five genes is possible within two weeks on $\sim 2 \mu \mathrm{g}$ of fetal DNA, there is a great need for other detection methods involving less DNA, more tests and a shorter turnaround time, to allow the analysis of more genes and thus to further increase the mutation detection rate. Furthermore, future clinical studies of mutationnegative cases, both prenatally and postnatally, are necessary to better define the inclusion criteria for NS testing.

\section{CONFLICT OF INTEREST}

The authors declare no conflict of interest.

\section{ACKNOWLEDGEMENTS}

We wish to thank all parents and referring doctors for their participation in this study. We are grateful to Kim van der Donk, Sanne de Wit and Edwin van Vught for expert technical assistance. We are thankful to Barbara Nolens for critical reading of the manuscript.

1 Allanson JE: Noonan Syndrome. J Med Genet 1987; 24: 9-13.

2 Noonan JA: Noonan syndrome. An update and review for the primary pediatrician. Clin Pediatr 1994; 33: 548-555.

3 Sharland M, Burch M, McKenna WM, Paton MA: A clinical study of Noonan syndrome. Arch Dis Child 1992; 67: 178-183.

4 Tartaglia M, Mehler EL, Goldberg R et al: Mutations in PTPN11, encoding the protein tyrosine phosphatase SHP-2, cause Noonan syndrome. Nat Genet 2001; 29 . 465-468.

5 Tartaglia M, Kalidas K, Shaw A et al: PTPN11 mutations in Noonan syndrome: molecular spectrum, genotype-phenotype correlation, and phenotypic heterogeneity. Am J Hum Genet 2002; 70: 1555-1563.

6 Schubbert S, Zenker M, Rowe SL et al: Germline KRAS mutations cause Noonan syndrome. Nat Genet 2006; 38: 331-336.

7 Roberts AE, Araki T, Swanson KD et al: Germline gain-of-function mutations in SOS1 cause Noonan syndrome. Nat Genet 2007; 39: 70-74.

8 Tartaglia M, Pennaccio LA, Zhao $\mathrm{C}$ et al: Gain-of-function SOS1 mutations cause distinctive form of Noonan syndrome. Nat Genet 2007; 39: 75-79.

9 Pandit B, Sarkozy A, Pannaccio LA et al: Gain-of-function RAF1 mutations cause Noonan and LEOPARD syndromes with hypertrophic cardiomyopathy. Nat Genet 2007; 39: 1007-1012.

10 Razzaque MA, Nishizawa T, Komoike $Y$ et al: Germline gain-of-function mutations in RAF1 cause Noonan syndrome. Nat Genet 2007; 39: 1013-1017.

11 Nava C, Hanna N, Michot C et al: Cardio-facio-cutaneous and Noonan syndromes due to mutations in the RAS/MAPK signalling pathway: genotypephenotype relationships and overlap with Costello syndrome. J Med Genet 2007; 44: 763-771.

12 Cirstea IC, Kutsche K, Dvorsky R et al: A restricted spectrum of NRAS mutations causes Noonan syndrome. Nat Genet 2010; 42: 27-29.

13 Martinelli S, De Luca A, Stellacci E et al: Heterozygous germline mutations in the CBL tumor-suppressor gene cause a Noonan syndrome-like phenotype. Am J Hum Genet 2010; 87: 250-257.
14 Hennekam RC: Costello syndrome: an overview. Am J Med Genet C Semin Med Genet 2003; 117C: 42-48.

15 Roberts A, Allanson J, Jadico SK et al: The cardiofaciocutaneous syndrome. J Med Genet 2006; 43: 833-842.

16 Tartaglia M, Gelb BD, Zenker M: Noonan syndrome and clinically related disorders. Best Pract Res Clin Endocrinol Metabl 2011; 25: 161-179.

17 van den Bosch T, van Schoubroeck D, Fryns JP, Naulaers G, Inion AM, Devriendt K: Prenatal findings in a monozygotic twin pregnancy with Costello syndrome. Prenat Diagn 2007; 22: 415-417.

18 Smith LP, Podraza J, Proud VK: Polyhydramnion, fetal overgrowth, and macrocephaly: prenatal ultrasound findings of Costello syndrome. Am J Med Genet 2009; 149A: 779-784.

19 Lin AE, O'Brien B, Demmer LA et al: Prenatal features of Costello syndrome: ultrasonographic findings and atrial tachycardia. Prenat Diagn 2009; 29: 682-690.

20 Witt DR, Hoyome HE, Zonana J et al: Lymphedema in Noonan syndrome: clues to pathogenesis and prenatal diagnosis and review of the literature. Am J Med Genet 1987; 27: 841-856.

21 Nisbet DL, Griffin DR, Chitty LS: Prenatal findings in Noonan syndrome. Prenat Diagn 1999; 19: 642-647.

22 Menashe M, Arbel R, Raveh D, Achiron R, Yagel S: Poor prenatal detection rate of cardiac anomalies in Noonan syndrome. Ultrasound Obstet Gynecol 2002; 19: 51-55.

23 Bekker MN, ATJI Go, van Vugt JMG: Persistence of nuchal edema and distended jugular lymphatic sacs in Noonan syndrome. Fetal Diagn Ther 2007; 22: 245-248.

24 Bakker M, Pajkrt E, Mathijssen IB, Bilardo CM: Targeted ultrasound examination and DNA testing for Noonan syndrome, in fetuses with increased nuchal translycency and normal karyotype. Prenat Diagn 2011; 31: 833-840.

25 Schlüter G, Steckel M, Schiffmann $\mathrm{H}$ et al: PrenatalDNA diagnosis of Noonan syndrome in a fetus with massive hygroma colli, pleural effusion and ascites. Prenat Diagn 2005; 25: 574-576.

26 Lee KA, Williams B, Roza $\mathrm{K}$ et al: PTPN11 analysis for the prenatal diagnosis of Noonan syndrome in fetuses with abnormal ultrasound findings. Clin Genet 2009; 75 : 190-194.

27 Houweling AC, de Mooij YM, van der Burgt I, Yntema HG, Lachmeijer AM, Go AT: Prenatal detection of Noonan syndrome by mutation analysis of the PTPN11 and the KRAS genes. Prenat Diagn 2010; 30: 284-286.

28 Musante L, Kehl HG, Majewski F et al: Spectrum of mutations in PTPN11 and genotype-phenotype correlation in 96 patients with Noonan syndrome and five patients with cardio-facio-cutaneous syndrome. Eur J Hum Genet 2003; 11: 201-206.

29 Yoshida R, Nagai T, Hasegawa T, Kinoshita E, Tanaka T, Ogata T: Two novel and one recurrent PTPN11 mutations in LEOPARD syndrome. Am J Med Genet 2004; 130A: 432-434.

30 Tartaglia M, Martinelli S, Stella L et al: Diversity and functional consequences of germline and somatic PTPN1 1 mutations in human disease. Am J Hum Genet 2006; 78: 279-290.

31 Schulz AL, Albrecht B, Arici $C$ et al: Mutation and phenotypic spectrum in patients with cardio-facio-cutaneous and Costello syndrome. Clin Genet 2008; 73: 62-70.

32 Baldassarre G, Mussa A, Dotta A et al: Prenatal features of Noonan syndrome: prelavence and prognostic value. Prenat Diagn 2011; 31: 949-954.

33 Zheng YM, Wang N, Li L, Jin F: Whole genome amplification in preimplantation genetic diagnosis. J Zhejiang Univ-Sci B (Biomed \& Biotechnol) 2011; 12: 1-11.

34 Marino B, Digilio MC, Toscano A, Gianotti A, Dallapicolla B: Congenital heart diseases in children with Noonan syndrome: an expanded cardiac spectrum with high prevalence of atrioventricular canal. J Pediatr 1999; 135: 703-706.

35 Bertola DR, Kim CA, Sugayama SMM et al: Cardiac findings in 31 patients with Noonan's syndrome. Arq Bras Cardiol 2000; 75: 409-412.

36 Croonen EA, van der Burgt I, Kapusta L, Draaisma JM: Electrocardiography in Noonan syndrome PTPN11 gene mutation - phenotype characterisation. Am J Med Genet 2008; 146: 350-353.

37 Arichon R, Heggesh J, Grisaru D et al: Noonan syndrome: a cryptic condition in early gestation. Am J Med Genet 2000; 92: 159-165. 